\author{
Danuta Ptaszycka-Jackowska \\ Jagellonian University in Cracow \\ dpj1@wp.pl
}

\title{
SEA CRUISES AS A NEW BRANCH OF THE TOURISM INDUSTRY
}

\begin{abstract}
The article presents sea cruises - a form of tourism which is not very common in Poland but flourishes in other parts of the world. The author describes world and European fleets, cruise routes, ports visited and elements of cruise organization. She presents a detailed illustration of the most powerful European company - the Italian Costa Crociere (Costa Cruises) - which organizes cruises in Europe and all over the world.
\end{abstract}

Key words: tourism geography, sea tourism, sea cruises, tourism fleet, Costa Crociere.

\section{INTRODUCTION}

After World War II, sea passenger shipping began slowly to transform itself into tourism cruising ${ }^{1}$ with stops at different ports for sight-seeing. This was because passenger lines were losing in competition with air transport. The process of cruise development accelerated in the 1980's and 90's, to become very dynamic in the last decade (2000-10) (L'activité..., 2003, CARTWRIGHT, BAIRD 1999, CHOMKA 2000). The increase in the number of cruise passengers over that period is estimated at $37 \%$.

A number of companies specializing in this type of tourism have appeared owning fleets of deep draught ocean-going ships and capable of organizing individual cruises for up to 3000 per ship.

Ships call at ports where tourists may find a wide offer of excursions, mainly by coach, with guides, and organized for different language groups.

The competition between individual companies is strong, especially as regards tourism routes, comfort of travel, ways of spending time on board, the variety and quality of the services offered, and price levels. The companies widely cooperate with external service providers and in searching for qualified staff. Its scale demonstrates that a new branch of the tourism industry has been born (Contribution..., 2010, DWYER, FORSYTH 1998).

In the Polish literature, sea tourism has been discussed by MIKA (2007) who identifies five forms:

- coastal navigation excursion ships;

- sea ferries;

- cargo ships;

- seagoing yachts;

- seagoing excursion ships.
MIKA devoted most of his attention to the last form, referring to it just as cruising (sea excursion tourism) and this article is also dedicated to this particular form. The author attempts to present the issue globally and in Europe, using the example of the largest European company and one of the largest in the world, the Italian Costa Crociere, which in 2008 celebrated its $60^{\text {th }}$ anniversary.

Finally, it should be stressed that while collecting data for the purposes of this article, the author found a number of discrepancies between different sources. Therefore, the figures quoted in the article should be treated as approximate, pointing mainly to the scale of the phenomenon described.

\section{SEA CRUISING GLOBALLY}

The global scale of the sea cruising phenomenon is illustrated by several figures. At present, there are about 300 large cruise ships, each accommodating over 500 passengers in cabins. It is estimated that these ships transport 13 million tourists annually. About 200,000 people are employed in the service of this transport sector and the cost of building a single ship reaches about 500 million dollars. Experts estimate that the cruise ship industry is one of the fastest growing branches of the tourism economy (WARD 2010, www.e-hotelarz.pl). Generally, in the early 2000 's globally, sea cruises averaged 9.5 million passengers annually and over the decade the number of passengers increased by nearly $37 \%$. It is estimated 
that they spent 48 billion dollars a year. American (6 million) and European (1.7 million) tourists constituted $81 \%$ of the total.

Sea cruises are organized by companies with various financial structures, often joint-stock companies. A company owns a fleet of passenger ships of similar tourist capacity, i.e. the number of places/beds in cabins with a large number of staff on land as well as at sea. On board the ratio of passengers to staff is $3: 1$ on average.

The companies choose the routes of their cruises and ports of departure, which are often outside their home country, within a cruising area, e.g. the Caribbean, Northern Europe or the Far East. During a cruise the ship calls at many ports where the tourists go on organized excursions.

The oldest companies launching tourism cruises, and which still exist today, were European companies. The earliest were established in the mid-19th c., e.g. Cunard - a British company set up in 1840 in which luxury cruises have always played a predominant role. It owned such famous ships as Queen Elisabeth I and II, Queen Mary I, and currently Queen Mary II and the newest - Queen Victoria.

A particular role was played by the Holland America Line, established in 1873 as a Dutch-American company (currently American), which specialized in transporting emigrants from Europe to North America. In 1895, the Holland America Line organized the first holiday cruise in the world, and in 1910 - the first voyage from New York to the Holy Land (www.venustour.pl).

A company of long experience is the Italian Costa Crociere, set up in 1948 originally for cargo shipping purposes, it soon reoriented itself towards sea cruises for tourists.

A number of cruise lines which are currently the largest were founded in the 1960's (e.g. the BritishAmerican Princess Cruises in 1965, NCL in 1966) and later (e.g. the American Carnival Cruise Line in 1973, the Italian MSC in 1988, the American Celebrity in 1989) (Safpol Travel). The youngest companies include Crystal Cruises (American, based in Los Angeles), set up in the early 1990's as well as the Spanish Iberocruceros, established in 2007 (Wikipedia Costa Cruises).

An analysis of the worldwide cruise market points to the strong domination of Europe and North America (Table 1). These two macro-regions concentrate $74 \%$ of the companies which organize sea cruises in the world, $85 \%$ of cruise ships and $87 \%$ of cabin places. Europe is in the lead, with $48 \%$ of companies, $45 \%$ of ships and $45 \%$ of cabin places. The African continent lacks this type of cruising resource and the rest of the world has few of them. This does not mean, however, that there are no cruises in those areas; they are simply organized by European and American companies.

T a b l e 1. World sea cruise fleets by size of ship - 2009

\begin{tabular}{|c|c|c|c|}
\hline \multirow{2}{*}{$\begin{array}{l}\text { Size of ship } \\
\text { (by number of } \\
\text { cabin places) }\end{array}$} & \multicolumn{3}{|c|}{ Number } \\
\hline & companies & ships & cabin places \\
\hline \multicolumn{4}{|c|}{ Europe } \\
\hline$>1000$ & 15 & 85 & 186000 \\
\hline $500-1000$ & 17 & 72 & 43300 \\
\hline$<500$ & 29 & 74 & 8870 \\
\hline Total & 61 & 231 & 238170 \\
\hline \multicolumn{4}{|c|}{ North America } \\
\hline$>1000$ & 8 & 76 & 192500 \\
\hline $500-1000$ & 6 & 16 & 12000 \\
\hline$<500$ & 23 & 110 & 18500 \\
\hline Total & 37 & 202 & 223000 \\
\hline \multicolumn{4}{|c|}{ Asia } \\
\hline$>1000$ & 3 & 19 & 41450 \\
\hline $500-1000$ & 4 & 7 & 5060 \\
\hline$<500$ & 5 & 13 & 1600 \\
\hline Total & 12 & 39 & 48110 \\
\hline \multicolumn{4}{|c|}{ South America } \\
\hline$>1000$ & - & - & - \\
\hline $500-1000$ & 10 & 20 & 13760 \\
\hline$<500$ & 3 & 4 & 630 \\
\hline Total & 13 & 24 & 14390 \\
\hline \multicolumn{4}{|c|}{ Australia } \\
\hline$>1000$ & 1 & 3 & 6000 \\
\hline $500-1000$ & - & $\begin{array}{ll}- \\
-\end{array}$ & - \\
\hline$<500$ & 7 & 10 & 650 \\
\hline Total & 8 & 13 & 6650 \\
\hline \multicolumn{4}{|c|}{ Central America } \\
\hline$>1000$ & - & - & - \\
\hline $500-1000$ & 1 & 1 & 700 \\
\hline$<500$ & - & - & - \\
\hline Total & 1 & 1 & 700 \\
\hline \multicolumn{4}{|c|}{ Africa } \\
\hline$>1000$ & - & - & - \\
\hline $500-1000$ & 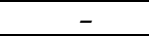 & 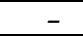 & - \\
\hline$<500$ & - & - & - \\
\hline Total & - & $\begin{array}{lll}- \\
\end{array}$ & - \\
\hline Globally & 132 & 510 & 531020 \\
\hline
\end{tabular}

S o u r c e: based on Cruise Chips List, Cruise Companies - www. cybercruises.com.

The concentration of large ships with over 1000 cabin places should be noted and companies from both regions own $88 \%$ of large cruise ships and $89 \%$ of places on them.

Tourism competition affects the sea cruising sector as well. As a result, companies from different countries form companies in order to protect their own business.

The largest corporation of that kind is the American, Carnival Corporation \& plc, consisting of the ten strongest American and European companies (Table 2). They own nearly 100 large ships with the total of about 220,000 cabin places. This means that the Carnival Corporation (...) holds $53 \%$ of all the large 
T a b l e 2. Carnival Corporation \& plc - the world's largest cruise company

\begin{tabular}{|l|l|c|c|c|}
\hline \multicolumn{1}{|c|}{ Company } & \multicolumn{1}{|c|}{$\begin{array}{c}\text { Home country } \\
\text { and main office }\end{array}$} & $\begin{array}{c}\text { No of } \\
\text { ships }\end{array}$ & $\begin{array}{c}\text { Average number } \\
\text { of places per ship }\end{array}$ & $\begin{array}{c}\text { Total tourist capacity } \\
\text { of ships }\end{array}$ \\
\hline Carnival Cruise Line & USA - Miami & 23 & 2500 & 57500 \\
\hline Costa Crociere & Italy - Genoa & 17 & 2500 & 42500 \\
\hline Aida Cruises & Germany - Rostock & 8 & 2000 & 3600 \\
\hline Princess Cruises & Great Britain/USA - California & 15 & 2500 & 17600 \\
\hline P \& O Cruise & Great Britain - Southampton & 8 & 2200 & 25500 \\
\hline Holland America Line & USA - Seattle & 15 & 1700 & 8000 \\
\hline P \& Cruise & Australia & 3 & 2000 & 5000 \\
\hline Cunard Line & Great Britain - Southampton & 4 & 2000 & 3000 \\
\hline Iberocruceros & Spain - Madrid & 4 & 1300 & 218800 \\
\hline Ocean Village & Great Britain - Southampton & 2 & 1500 & $\mathrm{x}$ \\
\hline Total & 98 & & \\
\hline
\end{tabular}

S o u r c e: based on www.cruiseeurope.com

cruises and $51 \%$ of cabin places. The second largest, but half the size, is the American Royal Caribbean Cruises Corporation, consisting of six companies, mostly American. There are also several small companies, consisting of the companies in a given country, e.g. TUI Travel plc in Great Britain (Table 3).

T a b l e 3. An example of a national company - TUI Travel plc (Great Britain)

\begin{tabular}{|l|l|c|c|c|}
\hline Company & $\begin{array}{c}\text { Home country } \\
\text { and main office }\end{array}$ & $\begin{array}{c}\text { No } \\
\text { of } \\
\text { ships }\end{array}$ & $\begin{array}{c}\text { Average } \\
\text { number } \\
\text { of places } \\
\text { per ship }\end{array}$ & $\begin{array}{c}\text { Total } \\
\text { tourist } \\
\text { capacity } \\
\text { of ships }\end{array}$ \\
\hline $\begin{array}{l}\text { Thomson } \\
\text { Cruises }\end{array}$ & $\begin{array}{l}\text { Great Britain - } \\
\text { Luton }\end{array}$ & 5 & 1200 & 6000 \\
\hline $\begin{array}{l}\text { Island } \\
\text { Cruises }\end{array}$ & Great Britain & 2 & 1500 & 3000 \\
\hline Total & 7 & $x$ & 9000 \\
\hline
\end{tabular}

S o u r c e: based on www.cruiseeurope.com.

We may observe a strong diversification in the development of companies organizing tourism cruises. There are countries, like the United States of America, Great Britain, Italy, or Germany, where companies specialize in cruises on large ships. There are also countries, where cruising takes place on small river and coastal boats, e.g. China (six companies which own 16 ships for 200 people each), Vietnam (one company with one ship for about 70) or New Guinea (one company with two ships for 40 people each). Other countries with small fleets include Chile (five companies with eight ships for 100 people each) and India (four companies with seven ships with 50 cabin places each). A relatively large fleet of river boats is found in France (one company with 26 boats, 180 places each).
A particular position among the European countries is occupied by Great Britain where there are 29 large ships, with a total of about 75,000 places, 15 mediumsized ships belonging to six companies (about 100,000 places), as well as 21 small ships (with less than 500 places), some of which are river boats. There are also 21 barge hotels.

Some countries have large sea-going yachts offering exclusive cruises, e.g. the USA has 12 such yachts and Ecuador has three.

At this point it is important to mention the cruise typology, quoted in the literature on the subject (www. croisiere.com). There are 10 types of cruises with one for cruising down the great rivers of the world 2 . Thus, there are the following nine types of sea cruises:

1) Coastal - by small boats, e.g. among the Greek, Adriatic or Red Sea islands;

2) 'Classic' sea - they last 8-12 and more days, following set routes and dates;

3) Short sea - shorter than the classic ones (2-6 days)

4) Stationary - with a break during the cruise; the break usually lasts for one week, serves mainly recreational purposes. The tourists stay at one of the visited ports and go back to the ship at the next rotation;

5) Theme cruises:

- art (music, theatre, dance),

- culture (literary, historical cruises combined with lectures, led by cruise hosts),

- natural history,

- cooking/gastronomy,

- sport (walks, golf),

- exploration cruises in the Antarctic or Arctic, on board a specially adjusted ship, in order to discover the harder to reach parts of the world,

6) Long-distance - a combination of travelling by air and sea: flying from one's own country to a distant 
port, then on a sea cruise (e.g. a flight from Italy to Shanghai and a cruise on the Chinese Sea);

7) Sailing - cruises by sailing ships of different sizes, exclusive;

8) Motivation - seminars, congresses, group trips.

This typology has been recently enlarged by a new type which appeared when a huge ship named 'Oasis of the Seas' was built whose cabins can accommodate 6360 passengers and 2000 staff (www.france-info. com). The enormous size of the ship greatly limits the possibility of docking or having traditional optional excursions organized at stopover ports. The 'Oasis...' was designed as an independent, floating leisure centre, offering the passengers a wide range of recreational activities. The author suggests that this type of cruise is referred to as a fixed recreation cruise.

On a global scale, there are platforms for cooperation between cruise companies and companies and cruise tourism experts. The most important one is the annual Cruise Shipping Conference, based in Miami, USA (webmaster@levoyageur.net).

Considering the scale, the use of cruise ships is strongly affected by issues of marine and harbour environment protection. Environmental issues are currently strongly highlighted in the activity of individual companies and are often an object of competition as regards obtaining certificates or distinctions. Particular attention is being paid to climate issues, the protection of air and water purity, waste disposal, and water reuse. Companies cooperate with various organizations and institutions such as the European Committee or the WWF. A special area of activity is the protection of the Mediterranean Sea Basin, where the heavy traffic of cruise ships is added to a similar traffic of cargo ships. Another area of activity is the protection of ports such as Venice.

\section{TOURISM SEA CRUISES ORGANIZED BY EUROPEAN COMPANIES}

In Europe, there are 13 countries with 29 companies specialized in organizing sea cruises (Table 4). It is worth noticing that not all coastal countries take part in organizing such cruises, e.g. Poland ${ }^{3}$, Sweden, Belgium, Estonia, Latvia or Russia. However, there is one country which does not have access to the sea (Switzerland) but has two companies, owned jointly with Kenya, where the ships are stationed. A situation when one company combines cruising with another function is rare. An example of such a company however is the Luis Cruise Line from Cyprus, established in 1935 and based in Nicosia with 12 ships and a chain of 26 hotels - 15 in Greece and 11 in Cyprus (www. venustour.pl).
Great Britain is the leader among the European countries as regards the number of companies (21), ships (70) and cabin places (nearly 88,000), as well as the number of cruise participants (over 1.5 million in 2009) (Table 5). The position of Italy is also interesting; it has only two companies, but owns only large ships and as regards the number of places it is the largest in this particular category. Apart from Great Britain and Italy, European leaders include Germany and Spain. We should stress here the relatively weak position of France, which in many other sectors of tourism occupies the top position in Europe and globally, has a well-developed coastline and ideal shipyards which build passenger ships as well (e.g. recently Queen Mary II), but at the same time does not offer so many tourism sea cruises.

The ranking of European countries as regards cruise fleets (Table 4) is based on the number of passengers (Table 5). In 2009, a total of nearly five million people went on sea cruises in Europe. The majority of them were British $(31.0 \%)$, followed by Germans $(21.7 \%)$, Italians (15.9\%) and Spaniards (12.6\%). In all countries there has been an increase in the number of passengers. The highest in 2009 (compared to 2008) was recorded in the Scandinavian countries (41\%), followed by Austria (27\%) and Spain (26\%). On a European scale it was $12 \%$.

The routes of cruises most frequently chosen by Europeans include the Mediterranean Sea (FOURNIER 2011) with the Canary Islands, the Azores and Madeira (2.8 million tourists in 2009), the Baltic Sea and Norwegian Fiords (884,000 tourists in 2009). In these last two regions the largest increase in the number of cruise participants is found (> 20\% compared to 2008). A smaller increase is observed in the number of Europeans travelling to the Caribbean (which also attract the French - see Table 6) and on other routes $(<19 \%$ ) (www.lhotelerie-restauration.fr). The dominance of the Mediterranean Sea $(67 \%$ of the overall European traffic in 2009) should be stressed, followed by the Caribbean, Antilles and Bermudas, but they constitute only 13.4\% (webmaster@levoyageur.net 2010).

An interesting phenomenon is the cruise traffic load of the ports, related to ships arriving and their tourists. The situation in some ports is illustrated in Table 7. The number of ships and tourists is comparable in such different port cities as St Petersburg (five million inhabitants) and Tallinn (400,000 inhabitants). On average, three large ships call at each of these harbours every day, bringing about 9000 tourists. Disregarding the possible rotation, in order to provide them with an appropriate service, there is a need for 220 coaches and 220 guides speaking in different languages in each of the cities. This is a much greater problem for Tallinn, a small city, than for the huge St Petersburg. 
T a b l e 4. Sea cruise fleets in European countries - 2009

\begin{tabular}{|c|c|c|c|c|c|c|c|c|c|c|c|c|c|c|c|}
\hline \multirow{4}{*}{$\begin{array}{l}\text { Home } \\
\text { country }\end{array}$} & \multicolumn{9}{|c|}{ Sea cruise fleets by number of places in cabins } & \multirow{2}{*}{\multicolumn{6}{|c|}{ Home country total }} \\
\hline & \multirow{2}{*}{\multicolumn{3}{|c|}{$\frac{>1000}{\text { number }}$}} & \multirow{2}{*}{\multicolumn{3}{|c|}{$\begin{array}{c}500-1000 \\
\text { number }\end{array}$}} & \multirow{2}{*}{\multicolumn{3}{|c|}{$\begin{array}{c}<500 \\
\text { number }\end{array}$}} & & & & & & \\
\hline & & & & & & & & & & & num & & & of the & btal \\
\hline & $\mathrm{C}^{\mathrm{a}}$ & $\mathrm{sh}^{\mathrm{b}}$ & places & $c^{a}$ & $\mathrm{sh}^{\mathrm{b}}$ & places & $\mathrm{C}^{\mathrm{a}}$ & $\operatorname{sh}^{b}$ & places & $\mathrm{C}^{\mathrm{a}}$ & $\mathrm{sh}^{\mathrm{b}}$ & places & $\mathrm{C}^{\mathrm{a}}$ & $\operatorname{sh}^{b}$ & places \\
\hline Great Britain & 6 & 36 & 75100 & 6 & 15 & 9450 & 9 & 19 & 3340 & 21 & 70 & 87890 & 34.0 & 30.4 & 36.9 \\
\hline Italy & 2 & 29 & 78500 & - & - & - & - & - & - & 2 & 29 & 78500 & 3.2 & 12.6 & 32.9 \\
\hline Germany & 2 & 10 & 20000 & 2 & 11 & 5500 & 7 & 23 & 1030 & 11 & 44 & 26530 & 18.1 & 19.1 & 11.1 \\
\hline Spain & 3 & 8 & 9300 & - & - & - & - & - & - & 3 & 8 & 9300 & 4.9 & 3.4 & 3.9 \\
\hline France & 1 & 1 & 1300 & 1 & 1 & 750 & 3 & 7 & 1590 & 5 & 9 & 3640 & 8.2 & 3.9 & 1.5 \\
\hline Greece & - & - & - & 4 & 12 & 8100 & 2 & 13 & 1150 & 6 & 25 & 9250 & 9.8 & 10.9 & 3.9 \\
\hline Finland & 1 & 1 & 1800 & - & - & - & 1 & 2 & 400 & 2 & 3 & 2200 & 3.2 & 1.3 & 0.9 \\
\hline Norway & - & - & - & 1 & 13 & 6500 & 1 & 2 & 200 & 2 & 15 & 6700 & 3.2 & 6.5 & 2.8 \\
\hline Portugal & - & - & - & 1 & 5 & 2500 & - & - & - & 1 & 5 & 2500 & 1.6 & 2.1 & 1.0 \\
\hline Cyprus & - & - & - & 1 & 10 & 8000 & 1 & 1 & 260 & 2 & 11 & 8260 & 3.2 & 4.7 & 3.5 \\
\hline Netherlands & - & - & - & 1 & 5 & 2500 & 2 & 3 & 300 & 3 & 8 & 2800 & 4.9 & 3.4 & 1.2 \\
\hline Croatia & - & - & - & - & - & - & 2 & 3 & 400 & 2 & 3 & 400 & 3.2 & 1.3 & 0.2 \\
\hline $\begin{array}{l}\text { Switzerland } \\
\text { / Kenia }\end{array}$ & - & - & - & - & - & - & 1 & 1 & 220 & 1 & 1 & 220 & 1.6 & 0.4 & 0.1 \\
\hline Total & 15 & 85 & 186000 & 17 & 72 & 43300 & 29 & 74 & 8890 & 61 & 231 & 238190 & 100.0 & 100.0 & 100.0 \\
\hline
\end{tabular}

$\mathrm{C}^{\mathrm{a}}$ - companies, $\mathrm{sh}^{\mathrm{b}}$ - ships.

S o u r c e: based on Cruise Chips List, Cruise Companies - www.cybercruises.com.

T a b l e 5. European sea cruise participants - 2007-9

\begin{tabular}{|c|c|c|c|c|c|}
\hline \multirow{2}{*}{$\begin{array}{c}\text { Participants' } \\
\text { home countries }\end{array}$} & \multicolumn{3}{|c|}{$\begin{array}{c}\text { No of participants } \\
\text { in thousands }\end{array}$} & \multirow{2}{*}{$\begin{array}{c}\text { Increase } \\
2008-9 \\
(\%)\end{array}$} & \multirow{2}{*}{$\begin{array}{c}\text { European } \\
\text { market } \\
\text { share } \\
(\%) 2009\end{array}$} \\
\hline & 2007 & 2008 & 2009 & & \\
\hline Great Britain & 1335 & 1477 & 1533 & 4 & 31.0 \\
\hline Germany & 763 & 907 & 1027 & 13 & 20.7 \\
\hline Italy & 640 & 682 & 790 & 16 & 15.9 \\
\hline Spain & 518 & 497 & 627 & 26 & 12.6 \\
\hline France & 280 & 310 & 347 & 12 & 7.0 \\
\hline $\begin{array}{l}\text { Scandinavian } \\
\text { countries }\end{array}$ & 94 & 123 & 174 & 41 & 3.4 \\
\hline Benelux & 82 & 92 & 109 & 19 & 2.2 \\
\hline Switzerland & 64 & 65 & 75 & 16 & 1.5 \\
\hline Austria & 52 & 59 & 75 & 27 & 1.5 \\
\hline Portugal & 20 & 28 & 30 & 8 & 0.6 \\
\hline Other & 155 & 183 & 184 & 1 & 3.6 \\
\hline Total & 4004 & 4422 & 4942 & 12 & 100.0 \\
\hline
\end{tabular}

S o u r c e: based on (webmaster@levoyageur.net) (2010).

The problem is different in Flåm, situated deep in a Norwegian fiord and inhabited by 300 people. The pier makes it possible for only one ship to moor and only one ship can call here daily. Despite the fact that all the inhabitants are involved in tourism, they are not capable of serving 3000 people at the same time. At the culmination of their stay, it is necessary to provide 70 coaches with guides, therefore Flåm needs help from the nearby town of Voss and city of Bergen.
T a b l e 6. Main routes of French tourists on sea cruises - 2008 and 2009 (in thousands)

\begin{tabular}{|l|r|r|c|}
\hline \multirow{2}{*}{ Routes } & \multicolumn{2}{|c|}{$\begin{array}{c}\text { No of tourists } \\
\text { in thousands }\end{array}$} & $\begin{array}{c}\text { \% of the } \\
\text { total } \\
-2009\end{array}$ \\
\cline { 2 - 3 } & 2008 & 2009 & \\
\hline Mediterranean Sea and Black Sea & 200 & 233 & 67.0 \\
\hline $\begin{array}{l}\text { Caribbean, Antilles, } \\
\text { Bermudas }\end{array}$ & 46 & 47 & 13.4 \\
\hline Scandinavia - Baltic Sea & 18 & 19 & 5.5 \\
\hline $\begin{array}{l}\text { Atlantic islands, Great Britain, } \\
\text { Western Europe }\end{array}$ & 14 & 11 & 3.2 \\
\hline Transatlantic cruises & 11 & 10 & 2.8 \\
\hline East: Asia - Australia & 3 & 4 & 1.1 \\
\hline South America & 3 & 3 & 0.8 \\
\hline $\begin{array}{l}\text { West Coast USA, Mexico, } \\
\text { Hawaii, Panama Canal }\end{array}$ & 1 & 1 & 0.3 \\
\hline Other routes & 7 & 13 & 3.6 \\
\hline $\begin{array}{l}\text { Charter, integrative, seminar } \\
\text { cruises }\end{array}$ & 6 & 8 & 2.3 \\
\hline Total & 310 & 347 & 100.0 \\
\hline
\end{tabular}

S o u r c e: based on webmaster@levoyageur.net (2010).

In this way cruise tourism here has an impact on the whole region. Its regional range is also seen in the optional excursions that are organized. It should also be said that the guides are sometimes foreign students spending their holidays in this way to earn their university fees ${ }^{4}$. 
$\mathrm{T}$ a b l e 7. Ships calling at ports and cruise tourists in 2010

\begin{tabular}{|l|c|c|}
\hline \multirow{2}{*}{ Ports } & \multicolumn{2}{c|}{ Number } \\
\cline { 2 - 3 } & ships & visitors \\
\hline \multicolumn{3}{|c|}{ Baltic ports } \\
\hline Copenhagen & 307 & 662000 \\
\hline St. Petersburg & 298 & 423931 \\
\hline Tallinn & 280 & 389370 \\
\hline Stockholm & 259 & 415000 \\
\hline Gdynia & 85 & 125372 \\
\hline Riga & 64 & 58564 \\
\hline Klaipeda Ports in Southern Norway \\
\hline \multicolumn{2}{|c|}{} \\
\hline Bergen & 241 & 34962 \\
\hline Geirangerfjord & 158 & 291877 \\
\hline Oslo & 150 & 210105 \\
\hline Stavanger & 111 & 175000 \\
\hline Flåm & 106 & 136908 \\
\hline
\end{tabular}

S o u r c e: Cruise Europe Statistics www.cruiseeurope.com.

The European Cruise Council (ECC) brings together 24 cruise ship companies (webmaster@levoyageur. net).

\section{COSTA CROCIERE - A CASE STUDY OF THE STRONGEST EUROPEAN CRUISE LINE}

Costa Crociere has been on the market since 1948. It is a joint-stock company, which owns 16 large ships accommodating about 1000 passengers. In total, the ships offer over 18,000 cabins with over 38,000 places (Table 8). The Costa fleet is very modern; 11 ships $(64.7 \%)$ were built in and after 2000 . Only three ships $(17.6 \%)$ come from the 1990's, and the remaining two are older, but regularly modernized (www.cruiseshipodyssey.com).

In 2011, Costa organized nearly 300 cruises (Table 9). The main routes included the Mediterranean Sea with the Canary Islands (131 cruises, 44.3\%), Northern Europe (55 cruises, 18.7\%) and the Far East (32 cruises, 10.9\%) (Fig. 1).

The growth of the Costa company is demonstrated not only by its modern ships, but also new routes of travel: in 2006 - the Far East, Dubai and the Arab Emirates, in 2007 - the Indian Ocean and in 2010 Greenland (Fig. 2). At the beginning of 2012 Costa organized its first, 100-day-long cruise around the world, including Australian ports for the first time. The concept of the 'Around the World' cruise comprises three stages: 'In Christopher Columbus' Footsteps' from Savona to Los Angeles (Fig. 3), 'In James Cook's Footsteps' - from Los Angeles to Singapore (Fig. 4), and 'In Marco Polo's Footsteps' - from Singapore back to Savona (Fig. 5) (Costa Cruise 2011 [Cruise catalogue]).

An analysis of Costa Crociere cruises shows that the numbers of cruises in individual months are relatively equal, with a slight domination in May (33 cruises), July (31) and August (30) and the smallest in February (18) and October (18). This relative regularity shows the company's efforts to make a steady and balanced use of its fleet.

T a b l e 8. Italian fleet of Costa Crociere 2011/12

\begin{tabular}{|l|c|c|c|c|}
\hline Name of ship & $\begin{array}{c}\text { Placed } \\
\text { in } \\
\text { service }\end{array}$ & $\begin{array}{c}\text { Modernization } \\
\text { year }\end{array}$ & $\begin{array}{c}\text { No of } \\
\text { cabins }\end{array}$ & $\begin{array}{c}\text { Tourist } \\
\text { capacity }\end{array}$ \\
\hline Costa Fascinosa & 2012 & - & 1508 & 3780 \\
\hline Costa Favolosa & 2011 & - & 1508 & 3780 \\
\hline Costa Deliziosa & 2010 & - & 1130 & 2826 \\
\hline Costa Luminosa & 2009 & - & 1130 & 2826 \\
\hline Costa Pacifica & 2009 & - & 1504 & 3780 \\
\hline Costa Serena & 2007 & - & 1500 & 3780 \\
\hline Costa Concordia & 2006 & - & 1500 & 3780 \\
\hline Costa Magica & 2004 & - & 1358 & 3470 \\
\hline Costa Fortuna & 2003 & - & 1358 & 3470 \\
\hline $\begin{array}{l}\text { Costa } \\
\text { Mediterranea }\end{array}$ & 2003 & - & 1057 & 2680 \\
\hline Costa Atlantica & 2000 & - & 1057 & 2680 \\
\hline Costa Victoria & 1996 & 2004 & 964 & 2394 \\
\hline $\begin{array}{l}\text { Costa } \\
\text { Romantica }\end{array}$ & 1993 & 2003 & 678 & 1697 \\
\hline Costa Classica & 1991 & 2001 & 654 & 1680 \\
\hline Costa Marina & 1969 & 2002 & 383 & 1000 \\
\hline Costa Allegra & 1969 & 2006 & 399 & 1000 \\
\hline Total & $\mathrm{x}$ & $\mathrm{x}$ & 17688 & 44623 \\
\hline
\end{tabular}

a The ship was wrecked on $15^{\text {th }}$ January 2012, after the article had been submitted for publication.

$\mathrm{S}$ o $\mathrm{u}$ r c e: based on www.cruisesshipodyssey.com Costa Cruises - Wikipedia.

$\mathrm{T}$ a b l e 9. Routes and the number of Costa Crociere cruises in 2011

\begin{tabular}{|c|c|c|c|}
\hline \multirow[b]{2}{*}{ Route } & \multirow{2}{*}{$\begin{array}{l}\text { Year of } \\
\text { inaugurati } \\
\text { ng route }\end{array}$} & \multicolumn{2}{|c|}{ Cruises } \\
\hline & & $\begin{array}{c}\text { numb } \\
\text { er }\end{array}$ & $\begin{array}{l}\% \text { of } \\
\text { total }\end{array}$ \\
\hline $\begin{array}{l}\text { Mediterranean Sea and } \\
\text { Canary Islands }\end{array}$ & $\cdot$ & 131 & 44.3 \\
\hline $\begin{array}{l}\text { Northern Europe - Baltic } \\
\text { Sea, Norwegian Fiords, } \\
\text { Spitsbergen, Iceland }\end{array}$ & . & 55 & 18.7 \\
\hline $\begin{array}{l}\text { Far East - China, South } \\
\text { Korea, Japan }\end{array}$ & 2006 & 32 & 10.9 \\
\hline $\begin{array}{l}\text { Caribbean (initially with the } \\
\text { USA) }\end{array}$ & 1959 & 23 & 7.7 \\
\hline Red Sea & & 19 & 6.4 \\
\hline $\begin{array}{l}\text { 'Small' cruises on the } \\
\text { Mediterranean Sea }\end{array}$ & $\begin{array}{l}\text { from } 1996 \\
\text { in winter }\end{array}$ & 14 & 4.7 \\
\hline Dubai and the Emirates & 2006 & 12 & 4.0 \\
\hline $\begin{array}{l}\text { 'Unique' transatlantic cru- } \\
\text { ises (incl. those to Greenland) }\end{array}$ & - & 6 & 2.0 \\
\hline Indian Ocean & 2007 & 4 & 1.3 \\
\hline Total & $\mathrm{x}$ & 296 & 100.0 \\
\hline
\end{tabular}

S o u r c e: based on Costa Cruises 2011 [Cruise catalogue].

There is a clear seasonal differentiation of the regions where cruises are organized. The most characteristic 


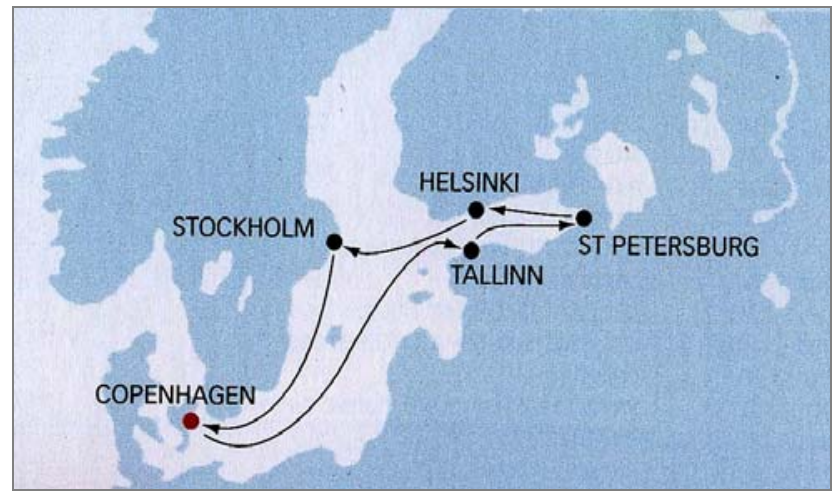

Fig. 1. A Costa Crociere route on the Baltic Sea S o u r c e: Costa Cruises 2011 [Cruise catalogue]

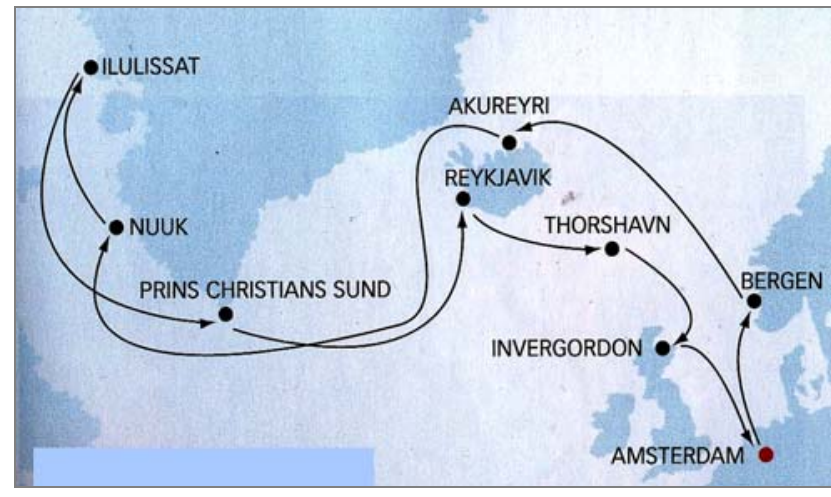

Fig. 2. The Costa Crociere route to Greenland S o u r c e: Costa Cruises 2011 [Cruise catalogue]

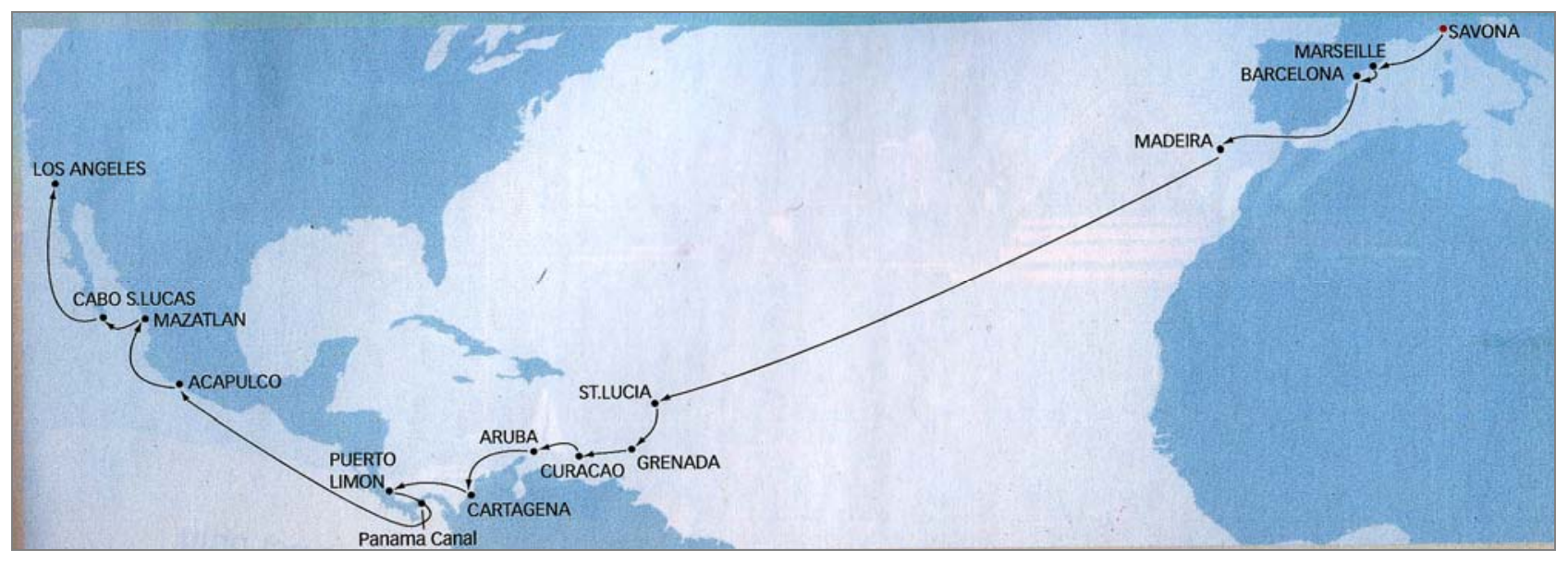

Fig. 3. In Christopher Columbus' Footsteps - Part I of the 'Round the world' cruise organized by Costa Crociere in 2012 S o u r c e: Costa Cruises 2011 [Cruise catalogue]

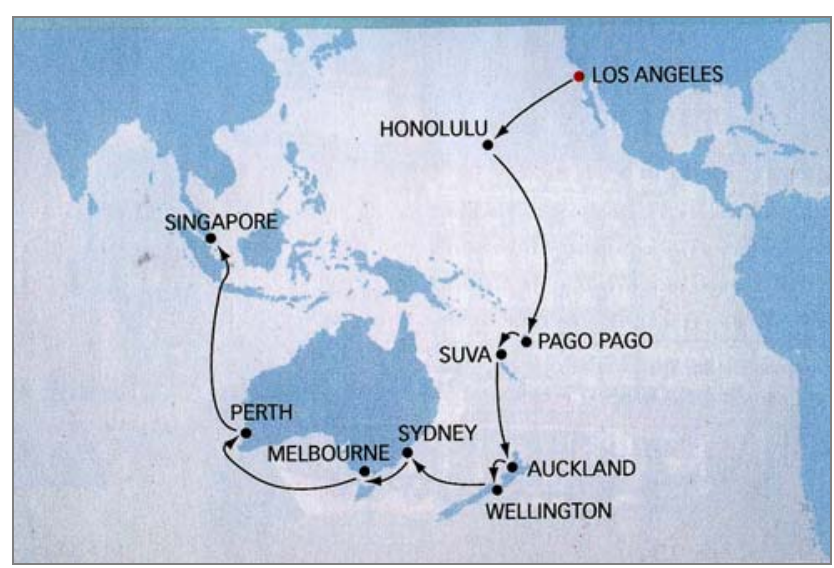

Fig. 4. In James Cook's Footsteps - Part II of the 'Round the world' cruise organized by Costa Crociere in 2012

S o u r c e: Costa Cruises 2011 [Cruise catalogue]

region is Northern Europe where cruises are organized between May and September, with their peak during the three summer months - June, July and August. Between December and April the cruises are organized mainly in South America, Dubai and the Emirates. The Mediterranean Sea basin is an interesting region, as there the cruising season lasts all year. The Canary Islands and the Caribbean also have long seasons ${ }^{6}$.

Costa cruises begin at 20 ports all over the world (Table 10). The main port of departure is Savona in Italy (99 cruises, $33.5 \%$ of the total), followed by Venice (40, i.e. $13.5 \%$ ). An important role is also played by Copenhagen (30, i.e. $10.1 \%$ ), as well as Sharm el Sheikht and Shanghai (Costa Cruise 2011 [Cruise catalogue]).

In the case when the port of departure is not in Italy, Costa Crociere follows the fly/sea approach, which means that it organizes charter flights for the passengers from Italy to the ports, e.g. from Milan to Buenos Aires, Dubai or Shanghai ${ }^{7}$.

Costa ships call at almost 200 ports all over the world (Table 11, Fig. 6) and those most intensely used are clearly visible. Most of them lie on the Mediterranean Sea and in Northern Europe, as well as in the Far East and South-Eastern Asia. 


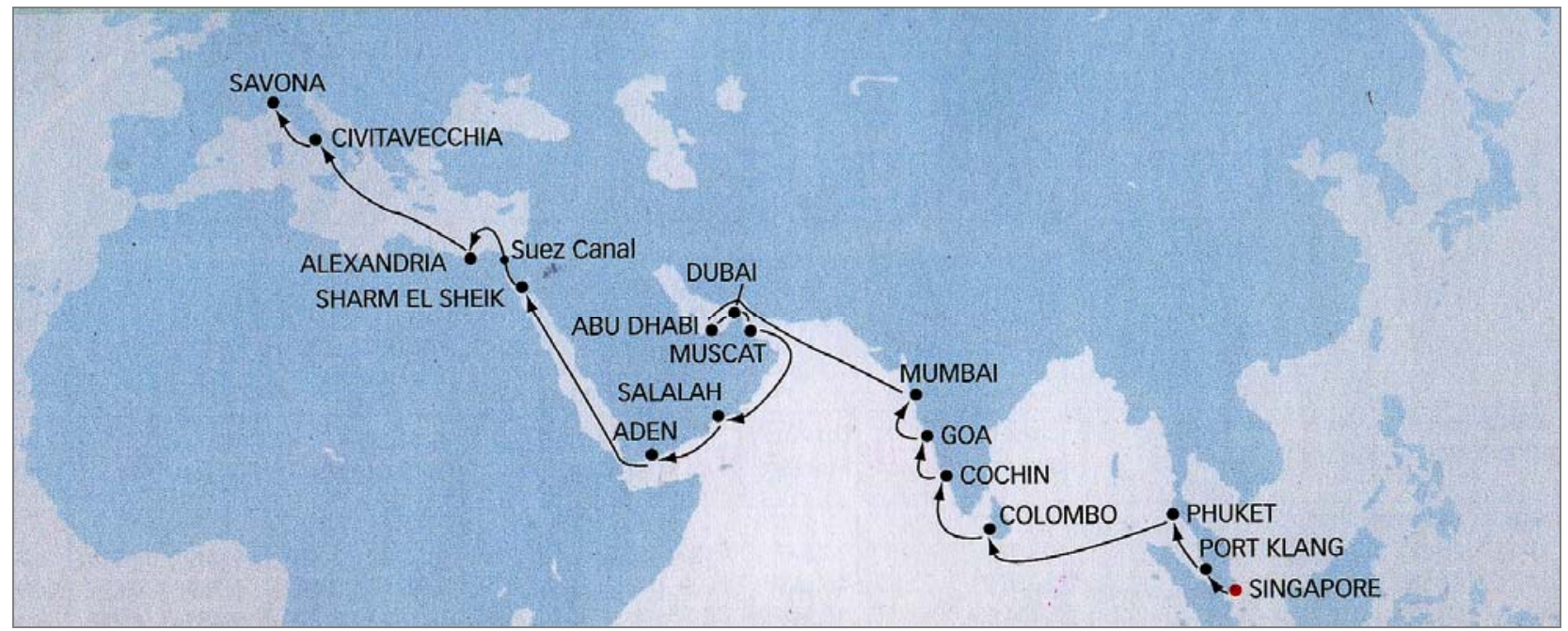

Fig. 5. In Marco Polo's Footsteps - Part III of the 'Round the world' cruise organized by Costa Crociere in 2012 S o u r c e: Costa Cruises 2011 [Cruise catalogue]

T a b le 10. Costa Crociere ports of departure in 2012

\begin{tabular}{|l|c|c|}
\hline \multirow{2}{*}{ Port of departure } & \multicolumn{2}{c|}{ Cruise departures } \\
\cline { 2 - 3 } & number & $\%$ of the total \\
\hline Savona (Italy) & 99 & 33.5 \\
\hline Venice (Italy) & 40 & 13.5 \\
\hline Copenhagen (Denmark) & 30 & 10.1 \\
\hline Skarm El Sheikht (Egypt) & 18 & 6.1 \\
\hline Shanghai (China) & 17 & 5.7 \\
\hline Amsterdam (Netherlands) & 13 & 4.4 \\
\hline Santos (Brazil) & 10 & 3.4 \\
\hline Other ports of departure (13) <10 & 69 & 23.3 \\
\hline Total & 296 & 100.0 \\
\hline
\end{tabular}

S o u r c e: based on Costa Cruises 2011 [Cruise catalogue].

T a b l e 11. Ports used by Costa Crociere ships by region (as of 2012)

\begin{tabular}{|l|c|c|}
\hline \multirow{2}{*}{ Region } & \multicolumn{2}{c|}{ Visited ports } \\
\cline { 2 - 3 } & number & $\%$ of total \\
\hline Mediterranean Sea & 37 & 19.3 \\
\hline Northern Europe & 32 & 16.7 \\
\hline The Far East and South-Eastern Asia & 27 & 14.0 \\
\hline Central America and the Caribbean & 15 & 7.8 \\
\hline South America & 13 & 6.8 \\
\hline Other & 68 & 35.4 \\
\hline Total & 192 & 100.0 \\
\hline
\end{tabular}

S o u r c e: Costa Cruises 2011 [Cruise catalogue].

Costa invests in the development of port terminals in order to make passenger and ship servicing more efficient. Recently large investments have been made in Savona (2003), Barcelona (2007) and Tianjin in China (2010) (www.costacroisieres.fr).
As has been mentioned before, at the ports visited the tourists may take part in optional excursions 8 . Table 12 presents an example of the excursions offered at Baltic ports in 2012 for those guided in French, during one cruise. The offer in St Petersburg is impressively wide, and includes not only visiting the most interesting historical monuments and the Hermitage, but also going to a ballet performance and a folklore evening. At several ports the offer includes trips to areas situated far away from the visited port city. Those excursions were often eco-tourism and took the tourists to interesting natural sites and regions, particularly valuable as regards sustainable development.

The development of Costa Crociere is also demonstrated by its growing number of passengers (tourists): in 1997 - 350,000, in 2007 - 1.1 million and in $2010-$ 1.5 million.

In 1997-2007 the number of cruise passengers tripled while in 2007-10 it increased by 35\% as a result of introducing new large ships (see Table 8) (www. tourmagazine.fr) (www.meretmarine.com).

In some countries, Costa is the most important company, serving the majority of inhabitants, e.g. in France, in 2003, 35\% of the French people participating in sea cruises chose Costa. France is the second most important market for Costa, after Italy, preceding Spain, Great Britain, Germany and Austria.

Costa employs 15,000 people: 14,000 working on board and 1000 on land, from 80 countries. The mean age of the employees is 30 and the mean period of employment - two years, $61 \%$ of the staff are male (www.linkedin.com) (Costa Crociere - Company Profile). The languages used on board Costa ships include 


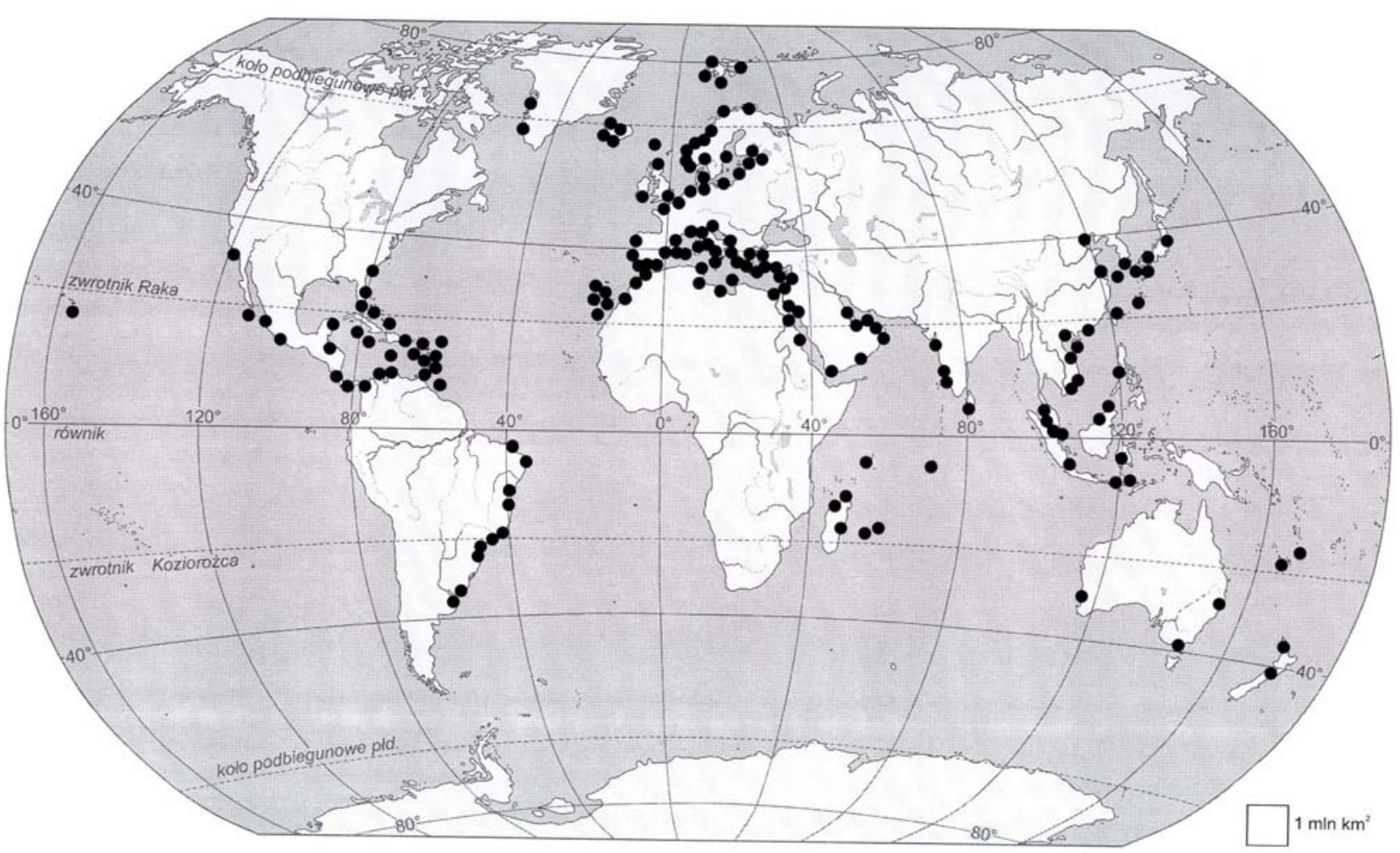

Fig. 6. Ports docked by Costa Crociere ships as of 2011 S o u r c e: based on Costa Cruises 2011 [Cruise catalogue]

T a b l e 12. Offers of excursions in port cities visited - a Costa Crociere Baltic port cruise in 2011

\begin{tabular}{|c|c|c|}
\hline \multirow[b]{2}{*}{ Visited port } & \multicolumn{2}{|c|}{ No of excursions } \\
\hline & in port city & $\begin{array}{c}\text { including longer } \\
\text { distances }\end{array}$ \\
\hline Tallinna ${ }^{a}$ & 4 & - \\
\hline St Petersburg & 15 & 5 \\
\hline Helsinki & 5 & 3 \\
\hline Stockholm & 6 & - \\
\hline Oslo & 3 & - \\
\hline Copenhagen & 5 & 1 \\
\hline
\end{tabular}

a The limited offers in Oslo and Tallinn were caused by the relatively short stopover of the ship.

S o u r c e: based on Tour magazine - the excursions 2011. Costa Luminosa.

Italian, English, French, German, Spanish, Russian and Portuguese.

In their efforts to provide a high standard of personnel service, Costa organizes its own training, mainly for the hotel stewards serving the passengers in cabins, as well as waiters and auxiliary staff. Training sessions are run at seven schools: in India (two), Italy, the Philippines, Indonesia, Brazil and Peru. On the one hand, the aim is to gain workers of standardized skills, and on the other to stimulate young people in developing countries. The period of employment on ships is short (from half to one year). The young go back to their countries with new qualifications and experience in tourism services.

Tourism activity on Costa ships is organized by 25,000 agencies in Europe and 65,000 in the world.

Costa Crociere is very active as regards environmental protection. In 2004 it was awarded the ISO 14001 Certificate for its high standards. The company particularly values the special 'Green Star' badge it received. In 2005 it started cooperation with the WWF in the area of marine environment protection, and in 2009 for the protection of the Mediterranean Sea in particular. Costa also signed a voluntary agreement for the protection of the environment of Venice, the 'Venetian Blue Flag'. Since 2005, many Costa ships have been taking part in monitoring climatic changes related to air pollution. The monitoring is conducted in cooperation with the European Commission. Costa ships also participate in monitoring electromagnetic emission (Costa Cruises 2011 [Cruise catalogue]).

Costa is the only European company which publishes annual reports on its activity in the field of environmental protection on ships. They regard, among other things, energy and fuel saving, desalinating sea water for drinking purposes, water reuse, segregation and the disposal of $100 \%$ of regular waste, and organizing eco-tourism (Costa Cruises 2011 [Cruise catalogue]). 
Costa has obtained certificates of safety (OHSAS 18 001), quality (UNI EN ISO 9001) and social responsibility (SA 8000) (www.costacruise.com).

\section{SEA CRUISING TOURISM - A BRANCH OF THE TOURISM INDUSTRY}

Sea cruising tourism is becoming a major part of the tourism industry. It operates in many different regions and number of aspects can be identified:

1. Creating the fleet - building the ships, their equipping (often luxurious, from expensive materials), exploiting the ships, developing services. The important aspects of all these activities include employment and the balance between cost and profit.

2. Services for the passengers as regards hotel facilities, gastronomy, entertainment, sport, culture, shopping, spa \& wellness, photography and tourism at the ports visited.

3. Cruise routes, ports visited - traditional routes, as well as new routes and ports included in an offer.

4. The influence of cruising tourism on the visited port destinations:

- docking at ports - it is necessary to have adequate terminal infrastructure ${ }^{9}$, using courier services, supplying provisions, paying harbour fees,

- developing local tourism services,

- developing tourism agencies which organize optional excursions - coaches, multilingual guides,

- developing the production and sale of souvenirs and regional articles,

- developing mailing services,

- an increase in the attendance and profits from admission fees at the sites visited,

- use of local gastronomy.

5. Training young workers in countries with a large workforce supply and a growing tourism market which will be able to absorb those qualified returning from work on ships.

6. The activities of companies which have suitable fleets and organize sea cruises:

- building their own fleet,

- creating a competitive offer as regards the standard of the facilities available on the ship, hotel, gastronomic and other services, cruise routes, systems of price discounts, the efficiency and appropriate behaviour of staff,

- cruise organization - the choice of routes and ports, frequency of cruises, marketing and promotion,

- cooperation with thousands of tourism agencies and offices and airlines when organizing the fly/sea cruises, cooperation with other service providers as regards port services and provision,
- creating large, strong companies, mainly international, accumulating capital and creating competition on the sea cruises market.

In recent years new companies have appeared, with a relatively large potential at the start.

\section{CONCLUSIONS}

Sea cruises are becoming an increasingly popular form of tourism, combining contact with seas and oceans while travelling to attractive coastlines in different countries. A ship makes a comfortable, fixed place of accommodation and relaxation, and the majority of days during the cruise are devoted to sightseeing. This is often limited to quick visits to the most important sites and buildings, and gives the tourist a sense of insufficiency, makes them interested in what they did not have time to see. On the one hand, this way of learning about the world corresponds to the current fast pace of living and gaining experience, but on the other it urges people to revisit given countries and individual destinations.

The strong competition on the cruise market leads to companies creating systems of offers and incentives in order to attract new and keep old clients, as well as sending their ships to remote, more obscure regions of the world.

Sea cruises as a developing branch of the tourism industry, brings the tourists benefits which are difficult to assess, but also gives economic and social benefits to the country of origin of a given cruise company and foreign markets.

\section{FOOTNOTES}

${ }^{1}$ In Polish terminology we find the term 'excursion cruises'. The author suggests using the term 'tourist cruises' so that the word 'excursion' refers to optional excursions, organized during the cruise at the visited ports.

2 The rivers include the Rhine, Danube, Seine, Rhone, Pau, Guadalquivir, Mosel, Volga, Yangtse, Mekong, Dnieper, and the Nile.

${ }^{3}$ It must be stressed here that the situation was completely different in inter-war Poland. There were companies called 'Źegluga Polska' and 'Polskie Towarzystwo Okrętowe' at that time. Apart from passenger cruises, they organized summer sea excursions under the slogan: 'work on the land, rest on the sea'. Four Polish ships - 'Kościuszko', 'Pułaski', 'Warszawa' and 'Polonia' - sailed in summer to Scandinavian countries, Latvia, Estonia, the USSR, Morocco, the Canary Islands and Madeira, Palestine, Greece, Turkey, North and South America (Cruise on the Baltic, 1929, Morskie wycieczki zagraniczne 1929, Letnie wycieczki morskie 1933, Wycieczki morskie 1938).

${ }^{4}$ Employing foreign students was also observed by the author in Greenland. 
${ }^{5}$ Costa Crociere was the first to organize winter cruises on the Mediterranean Sea in 1966.

${ }^{6}$ Costa Crociere launched cruises to the Caribbean in 1959.

7 The fly/sea system has been used by Costa Crociere since 1969. The company was the first to introduce it.

8 The offer of optional excursions at port destinations varies thematically. There are cultural, panoramic (going to viewing points) and visiting the major buildings and sites visited in a given town or city, shopping, sport, ecological, culinary (in cooperation with the Michelin Gastronomic Guide) and ethnographic excursions (Costa Cruises 2012 [Cruise catalogue]).

9 Some ports lack proper infrastructure. Ships lie at anchor at a roadstead and the tourists are transported to the coast in boats. At some ports the hosts appreciate the economic role of receiving large tourist ships and adjust the wharfs to suit their needs, as well as building terminals (e.g. in recent years in St Petersburg). There are situations when the cruise companies themselves invest in terminals (Cf. Chapter 4).

Translated by Ewa Mossakowska

\section{BIBLIOGRAPHY}

L'activité des croisières dans le monde, 2003, Organisation Mondiale du Tourisme, Madrid.

CARTWRIGHT R., BAIRD C., 1999, The Development and Growth of the Cruise Industry, Butterworth, Heinemann, Oxford.

CHOMKA M., 2000, Turystyka morska: zarys problematyki, Wyższa Szkoła Turystyki i Hotelarstwa, Gdańsk.

Contribution of Cruise Tourism to the economies of Europe, 2010, GP Wild (International) Ltd., European Cruise Council, Brussels-London.

Costa Cruises 2011 [Cruise catalogue].

Costa Cruises 2012 [Cruise catalogue].

Costa Cruises, Wikipedia.
Cruise Ships List, Cruise Companies, www.cybercruises.com. Cruise on the Baltic, 1929, "Żegluga Polska”, Warszawa.

DWYER L., FORSYTH P., 1998, Economic Significance of Cruise Tourism, Annals of Tourism Research, 25, 2, pp. 393-415.

FOURNIER C., 2011, Le tourisme de crosières en Méditerranée, Géoconfluence, marzec, pp. 1-13.

GRENIER A.A., 2008, Le tourisme de croisière. Téoros, Revue de recherche en tourisme, 27/2, pp. 36-48.

Le marché de la croisière. Bilan 2010, Conference de Presse de l'Association Française des Compagnies de Croisières, 24 mars 2011, www.afcc-croisieres.fr.

Letnie wycieczki morskie 1933, Warszawa [1933], Polskie Transatlantyckie Towarzystwo Okrętowe. Linia Gdynia-Ameryka.

MIKA M., 2007, Turystyka morska, [w:] W. Kurek (red.), Turystyka, Wyd. Naukowe PWN, Warszawa, pp. 235-243.

Morskie wycieczki zagraniczne, Warszawa 1929, „Żegluga Polska".

RITTER W., SCHAFFER C., 1998, Cruise Tourism: A Chance of Sustainability, Tourism Recreation Research, 10, 2, pp. 164-188.

Tour magazine - nos excursions. 2011, Costa Luminosa.

WARD D., 2010, Complete Guide to Cruising \& Cruise Ships, Berlitz Publishing, London.

Wycieczki morskie 1938, 1938 Warszawa, Gdynia-Ameryka. Linie Żeglugowe.

www.costacroisieres.fr.

www.costacruise.com.

www.croisiere.com.

www.cruiseeurope.com.

www.cruiseshipodyssey.com.

www.e-hotelarz.pl.

www.lhotelerie-restauration.fr.

www.linkedin.com

www.meretmarine.com.

www.niebieskamila.pl.

www.rejsy.pl.

www.safpoltravel.pl.

www.tourmagazine.fr.

webmaster@levoyageur.net (2010 r.). 